\title{
Approach to inguinal hernia in high-risk geriatric patients: Should it be elective or emergent?
}

\author{
Rıza Gürhan Işıl, M.D., ${ }^{1}$ Pınar Yazıcı, M.D.,, Uygar Demir, M.D.,, Cemal Kaya, M.D.,' \\ Özgür Bostancı, M.D., ${ }^{1}$ Ufuk Oğuz İdiz, M.D., ${ }^{1}$ Canan Tülay Işıl, M.D., ${ }^{2}$ \\ Mahmut Kaan Demircioğlu, M.D., ${ }^{1}$ Mehmet Mihmanlı, M.D. ${ }^{1}$ \\ ${ }^{1}$ Department of General Surgery, Şişli Hamidiye Etfal Training and Research Hospital, İstanbul-Turkey \\ ${ }^{2}$ Department of Anesthesia and Reanimation, Şişli Hamidiye Etfal Training and Research Hospital, İstanbul-Turkey
}

\begin{abstract}
BACKGROUND: Elderly patients are more prone to have inguinal hernia due to weakened abdominal musculature. However, surgical repair of inguinal hernia (SRIH) may not be performed or may be delayed due to greater risk in presence of comorbidities. Present study is investigation of outcome of elective and emergency SRIH in geriatric patients.
\end{abstract}

METHODS: Records of total of 384 high-risk (American Society of Anesthesiology classification III-IV) patients aged >65 years who underwent SRIH between January 2010 and December 2014 were reviewed. Patients were divided into 2 groups according to procedure type: elective (Group EL) or emergency (Group EM). Demographic features and surgical and postoperative period data of 2 groups were recorded and compared.

RESULTS: Demographic data were similar, but number of ASA IV patients was greater in Group EM. Frequency of intestinal resection was significantly greater in emergency surgery group (I\% vs $21 \% ; \mathrm{p}<0.0 \mathrm{I})$. Length of hospital stay $(\mathrm{I} .3$ days vs 7.9 days; $p<0.0 \mathrm{I})$ and intensive care unit stay $(0.17$ days vs 4.04 days; $p<0.01)$ were also greater in Group EM. Morbidity $(I \%$ vs $24 \% ; p<0.01)$ and mortality ( $0.3 \%$ vs II\%; $\mathrm{p}<0.0 \mathrm{I})$ were also significantly higher in Group EM compared to elective SRIH group.

CONCLUSION: Emergency inguinal hernia surgery is associated with significantly higher morbidity and mortality compared with elective SRIH in high-risk geriatric patients. Elective hernia repair in these patients should be considered to reduce risk of need for intestinal resection as well as length of hospital stay.

Keywords: Emergency surgery; geriatric; high risk; incarceration; inguinal hernia.

\section{INTRODUCTION}

Improvement in global healthcare delivery has led to increase in aging population worldwide. An estimated 6 million people were older than 65 years of age in our country as of 2014. ${ }^{[1]}$ Presence of co-morbid conditions in the elderly is known to be associated with high risk of surgical morbidity and mortality. In the absence of symptoms, surgical treatment is usually not performed or is delayed due to risk of morbidity. Conse-

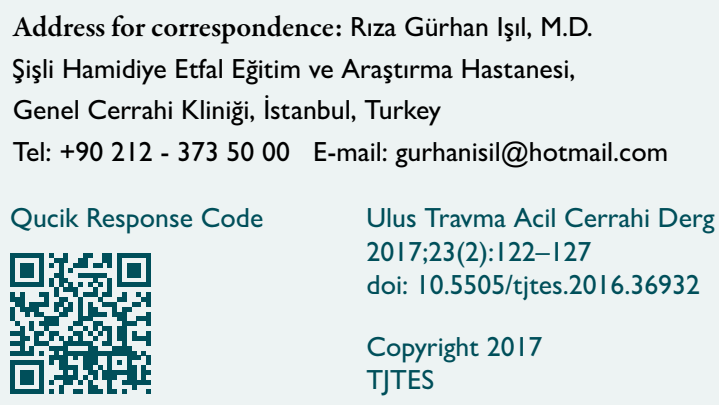

quently, incidence of emergency surgeries among this patient population has increased significantly in recent years.

Prevalence of inguinal hernia in the elderly is higher than in young people. One reason for this is progressive weakening of collagen tissue of the abdominal wall with age. ${ }^{[2]}$ Recent guidelines issued by the European Hernia Association recommend watchful waiting in asymptomatic patients and patients with mild symptoms or co-morbid conditions. ${ }^{[3]}$ Higher risk of morbidity is associated with emergency surgical repair of inguinal hernia (SRIH). ${ }^{[4,5]}$ This study is an investigation of outcomes of elective and emergency SRIH in high-risk patients (American Society of Anesthesiologists [ASA] score >III).

\section{MATERIALS AND METHODS}

The present study is retrospective analysis of 1824 elderly patients (age $>65$ years) who underwent elective or emer- 
gency inguinal hernia repair at hospital between January 2010 and December 20I4. In all, 1697 patients had SRIH under elective conditions, while 127 underwent emergency SRIH. Of total, 384 had ASA score greater than III and were considered high-risk patients. Study included only high-risk patients, who were then divided into 2 groups according to procedure performed: elective SRIH (Group EL, $n=312$ ) and emergency SRIH (Group EM, n=72). Medical records were examined to extract clinical, laboratory, and postoperative data on all study participants. Collected data included demographic characteristics, co-morbid conditions, ASA score (>III), operative procedure, duration of hospital/intensive care unit (ICU) stay, and pre and postoperative morbidity parameters. All data were recorded in institutionally approved database and analyzed using SPSS software, version 15.0 (IBM Corp., Armonk, NY, USA). Kolmogorov-Smirnov test was used to test for normal distribution of parameters. Continuous variables are expressed as mean \pm SD and categorical variables as reported as numbers and percentages. Student's t-test and Mann-Whitney $U$ test were used in comparison of means of continuous variables, and chi-square and Fisher's exact tests were used to evaluate differences in proportions. Statistical significance was accepted at $p$ value of $<0.05$.

Table I. Demographic features, perioperative data, postoperative complications, and co-morbidities

\begin{tabular}{|c|c|c|c|c|c|c|c|c|c|}
\hline & \multicolumn{4}{|c|}{ Group elective $(n=3 \mid 2)$} & \multicolumn{4}{|c|}{ Group emergency $(n=72)$} & \multirow[t]{2}{*}{$\mathbf{p}$} \\
\hline & $\mathbf{n}$ & $\%$ & Mean $\pm S D$ & Min.-Max. & $\mathbf{n}$ & $\%$ & Mean $\pm S D$ & Min.-Max. & \\
\hline Age & & & $77.1 \pm 7.6$ & $65-100$ & & & $77.3 \pm 7.7$ & $65-99$ & 0.935 \\
\hline \multicolumn{10}{|l|}{ Sex } \\
\hline Female & 39 & 13 & & & 12 & 7 & & & 0.348 \\
\hline Male & 273 & 88 & & & 60 & 83 & & & \\
\hline \multicolumn{10}{|l|}{ ASA } \\
\hline III & 269 & 86 & & & 18 & 5 & & & $<0.00 I^{*}$ \\
\hline IV & 43 & 14 & & & 50 & 9 & & & \\
\hline $\mathrm{V}$ & 0 & 0 & & & 4 & 5 & & & \\
\hline \multicolumn{10}{|l|}{ Operation } \\
\hline Hernia repair (mesh) & 310 & 99 & & & 55 & 77 & & & $<0.00 I^{*}$ \\
\hline Hernia repair+bowel resection & 2 & 1 & & & 17 & 3 & & & \\
\hline \multicolumn{10}{|l|}{ Result } \\
\hline Discharge & 311 & 100 & & & 63 & 87 & & & $<0.00 I^{*}$ \\
\hline Exitus & 1 & 0 & & & 9 & 3 & & & \\
\hline \multicolumn{10}{|l|}{ Complication } \\
\hline Yes & 3 & 1 & & & 20 & 8 & & & $<0.00 I^{*}$ \\
\hline No & 309 & 99 & & & 52 & 72 & & & \\
\hline Anastomosis leakage & 1 & 0 & & & 3 & 4 & & & \\
\hline Hematoma & 0 & 0 & & & 6 & 7 & & & \\
\hline Scrotal edema & 1 & 0 & & & 0 & 0 & & & \\
\hline Wound infection & 1 & 0 & & & II & 5 & & & \\
\hline Hospital stay & & & $1.3 \pm 1.0$ & $\mathrm{I}-14$ & & & $7.9 \pm 12.3$ & $2-82$ & $<0.00 I^{*}$ \\
\hline \multicolumn{10}{|l|}{ Intensive care unit stay } \\
\hline Yes & 38 & 12 & & & 71 & 99 & & & $<0.00 I^{*}$ \\
\hline No & 274 & 88 & & & 1 & I & & & \\
\hline \multicolumn{10}{|l|}{ Co-morbidity } \\
\hline Type 2 diabetes mellitus & 28 & 9 & & & 12 & 15 & & & 0.054 \\
\hline End stage renal disease & 5 & 2 & & & 2 & 2 & & & 0.620 \\
\hline COPD & 310 & 99 & & & 65 & 90 & & & $<0.001$ \\
\hline Coronary heart disease & 308 & 99 & & & 50 & 9 & & & $<0.001$ \\
\hline
\end{tabular}

ASA: American Society of Anesthesiologists; COPD: Chronic obstructive pulmonary disease; SD: Standard deviation; Min.: Minimum; Max.: Maximum. ${ }^{*} \mathrm{P}<0.05$ is statistically significant. Independent samples t-test / Mann-Whitney $U$ test / Chi-square test (Fischer's exact test). 


\section{RESULTS}

Demographic and clinical characteristics of both groups are provided in Table I. Groups were comparable in terms of age and gender. There were more patients with ASA IV status in Group EM than Group EL (61\% vs 14\%; $\mathrm{p}=0.000)$. Incidence of cardiac and respiratory disease was also greater in Group EM than Group EL. Most often, general anesthesia was used in Group EM (95\%), whereas only 8 patients (2.5\%) underwent surgery with general anesthesia in Group EL $(p<0.01)$. Significantly more patients in Group EM had concomitant bowel resection compared to Group EL ( $3 \%$ vs I\%; $<<0.05)$, while incidence of laparotomy was only $3 \%$ in Group EM.
Emergency patients also stayed longer in the ICU $(0.17 \pm 0.8$ days vs $4.04 \pm 10.7$ days; $\mathrm{P}<0.0 \mathrm{I})$ and hospital ( $\mathrm{I} .3 \pm \mathrm{I}$ days vs $7.9 \pm 12.2$ days; $p<0.01)$. Furthermore, they had greater incidence of postoperative morbidity ( $1 \%$ vs $24 \%$; $p<0.00 I$ ) and mortality $(0.3 \%$ vs II \%; $<<0.001)$.

Significant factors found in univariate analysis to predict postoperative complications were ASA score, end-stage renal disease (ESRD), and length of ICU/hospital stay. Multivariate analysis of these factors revealed ESRD and length of ICU/ hospital stay as independent predictors $(p<0.05)$ of postoperative complications (Table 2). Four factors: ASA score, comorbid conditions (ESRD), length of ICU/hospital stay, and

Table 2. Morbidity

\begin{tabular}{|c|c|c|c|c|c|c|}
\hline \multirow[t]{2}{*}{ Morbidity } & \multicolumn{3}{|c|}{ Univariate model } & \multicolumn{3}{|c|}{ Multivariate model } \\
\hline & OR & $95 \% \mathrm{Cl}$ & $\mathbf{p}$ & OR & $95 \% \mathrm{Cl}$ & $\mathbf{p}$ \\
\hline Age & 1.01 & $1.07-0.96$ & 0.730 & & & \\
\hline Gender & 1.02 & $3.57-0.29$ & 0.972 & & & \\
\hline American Society of Anesthesiologists score & 7.99 & $3.57-3.53$ & $<0.001^{*}$ & & & \\
\hline Type 2 diabetes & 2.59 & $0.28-7.40$ & 0.076 & & & \\
\hline End-stage renal disease & 13.4 & $0.28-63.91$ & $0.001^{*}$ & 22.3 & $3.2-156$ & $0.002^{*}$ \\
\hline Chronically obstructive pulmonary disease & 0.50 & $0.28-4.17$ & 0.521 & & & \\
\hline Coronary heart disease & 0.31 & $0.28-0.98$ & 0.051 & & & \\
\hline Spinal/general anesthesia & 11.4 & $71.7-1.80$ & $0.010^{*}$ & & & \\
\hline Inguinal incision/laparotomy & 26.9 & $170.4-4.25$ & $<0.001^{*}$ & & & \\
\hline Intensive care unit stay & 1.27 & $3.57-1.10$ & $<0.001^{*}$ & 1.72 & $1.31-2.25$ & $<0.00 I^{\prime}$ \\
\hline Hospital stay & 1.41 & $3.57-1.24$ & $<0.001^{*}$ & 1.99 & $2.59-1.54$ & $<0.00 I^{\prime}$ \\
\hline
\end{tabular}

$\mathrm{Cl}$ : Confidence interval; OR: Odds ratio. " $\mathrm{p}<0.05$ is statistically significant. Independent samples t-test / Mann-Whitney U test / Chi-square test (Fischer's exact test).

Table 3. Mortality

\begin{tabular}{|c|c|c|c|c|c|c|}
\hline \multirow[t]{2}{*}{ Morbidity } & \multicolumn{3}{|c|}{ Univariate model } & \multicolumn{3}{|c|}{ Multivariate model } \\
\hline & OR & $95 \% \mathrm{Cl}$ & $\mathbf{p}$ & OR & $95 \% \mathrm{Cl}$ & $\mathbf{p}$ \\
\hline Age & 1.0 & $0.9-1.1$ & 0.483 & & & \\
\hline Gender & 0.6 & $0.1-2.9$ & 0.530 & & & \\
\hline American Society of Anesthesiologists score & 17.1 & $4.6-63.9$ & $<0.001^{*}$ & 13.8 & $2.4-80.9$ & $0.004^{*}$ \\
\hline Type 2 diabetes & 9.7 & $35.1-2.7$ & $0.00 I^{*}$ & & & \\
\hline End-stage renal disease & 39.6 & $100<-7.4$ & $<0.00 I^{*}$ & 36.8 & $2.8-489$ & $0.006^{*}$ \\
\hline Chronically obstructive pulmonary disease & 26.3 & $5.4-127.0$ & $<0.001^{*}$ & & & \\
\hline Coronary heart disease & 0.2 & $0.6-0.0$ & $0.009^{*}$ & & & \\
\hline Spinal/general anesthesia & 31 & $5-211$ & $<0.001^{*}$ & 14.7 & $1.2-188.0$ & $0.039^{*}$ \\
\hline Inguinal incision/laparotomy & 249 & $24-2569$ & $<0.00 I^{*}$ & 132.4 & $10.4-1694$ & $<0.00$ I $^{*}$ \\
\hline Intensive care unit stay & 1.4 & $1.2-1.6$ & $<0.001^{*}$ & & & \\
\hline Hospital stay & I.I & $1.0-1.2$ & $0.004^{*}$ & & & \\
\hline Postoperative complications & 0.1 & $0.0-0.3$ & $<0.001^{*}$ & & & \\
\hline
\end{tabular}

ICU: intensive care unit; OR: Odds ratio. " $\mathrm{p}<0.05$ is statistically significant. Independent samples t-test / Mann-Whitney U test / Chi-square test (Fischer's exact test). 
postoperative complications predicted mortality in univariate analysis, while ASA score, incision type, anesthesia type, and ESRD were determined to be independent predictors of mortality in multivariate analysis (Table 3). In all, 10 patients died; mean $\pm S D$ age was $82.7 \pm 4.5$ years. Nine of these patients were in Group EM and only I belonged to Group EL. ASA score was IV in 9 of these patients and $V$ in the remaining patient. Reasons for death were postoperative myocardial infarction (MI) in Group EL, and sepsis $(n=I)$, postoperative MI $(n=2)$, or respiratory complications $(n=6)$ in Group EM patients.

\section{DISCUSSION}

Study results indicate that there is higher risk of morbidity and mortality associated with emergency SRIH in geriatric patients with high ASA score. Moreover, these patients are more likely to have higher risk of incarcerated or strangulated hernia and thus undergo small bowel resection. These factors can lead to longer ICU and hospital stay among this group of patients.

Surgery as treatment option in the elderly has been topic of interest for most clinicians over the past few decades. The reason for this widespread concern is effect of improved global healthcare, which has led to an aging population. ${ }^{[6]}$ Among common surgical procedures worldwide, SRIH is one of the most frequently performed, especially in males older than 50 years of age. Incidence of inguinal hernia increases with progressive weakening of collagen tissue. ${ }^{[7,8]}$ Surgical repair of herniated tissue is best known treatment option; however, with presence of co-morbid conditions that may occur with old age, treating elderly patients who present with hernia can be challenging. Previous studies have described safety and efficacy of SRIH among elderly patients. Nevertheless, higher risk of complications associated with SRIH and longer hospital stay have been reported in the elderly patient population compared with younger patients. ${ }^{[9]}$ For this reason, in patients with appreciable risk factors, most surgeons resort to delay of elective surgery due to asymptomatic nature of inguinal hernia. Statement by the Inguinal Hernia: Conservative or Operative Approach Trialists' Collaboration indicated that life expectancy for elderly male inguinal hernia patients associated with watchful waiting and with surgery differ very little. In cases of asymptomatic or mildly symptomatic patients, there seems to be no difference in pain relief between watchful waiting and operation. ${ }^{[10]}$ Furthermore, in 2013 study conducted by Amato et al.." ${ }^{[1]}$ authors reported that high-risk (ASA III-IV) elderly patients could undergo SRIH without limitations (existing co-morbidities). They demonstrated that high ASA score and comorbidities had no effect on operative success in elderly patients.

Although consensus regarding timing of surgical intervention for asymptomatic elderly patients with comorbidities hasn't been reached yet, need for in-depth risk-benefit analysis involving both patients and surgeons cannot be denied. At our center, patients and their families are usually involved in making final decision about surgical treatment after patients complete their preoperative anesthesia and operative risk evaluation.

Previous studies have proven that high risk of morbidity or mortality among the elderly is not associated with old age alone, but with presence of underlying co-morbid conditions. ${ }^{[4,12,13]}$ Abete et al. ${ }^{[14]}$ recently reported that with effective preoperative anesthesia and risk assessment evaluation, better postoperative outcomes can be achieved. In another study, by Gunnarsson et al.," ${ }^{[15]}$ patients aged over 75 years who underwent elective inguinal hernia repair had promising post-operative outcomes. The authors concluded that SRIH in elderly population is worthwhile and highly appreciated by patients. ${ }^{[16]}$

Compared to young patients, elderly patients are more likely to experience complicated inguinal hernia (incarceration or strangulation). ${ }^{[1]}$ Compared to elderly patients, time from diagnosis to inguinal hernia repair is usually shorter in young patients, which might explain lower incidence of complicated inguinal hernia. Other reasons for choosing conservative methods over surgical treatment may include presence of co-morbid conditions. ${ }^{[12]}$ About $90 \%$ of the patients who had emergency SRIH in our study had chronic obstructive pulmonary disease, $9 \%$ had chronic heart disease, $15 \%$ had type 2 diabetes, and $2 \%$ had end-stage renal disease. In elective SRIH group, $99 \%$ of the patients had chronic obstructive pulmonary disease, $99 \%$ had chronic heart disease, $9 \%$ had type 2 diabetes, and $2 \%$ had end-stage renal disease. These results seem to be confusing; however, $61 \%$ of emergency surgery group were ASA IV classification and $5 \%$ were ASA V. In elective surgery group, $86 \%$ were ASA III and I4\% were ASA IV. This indicates that patients who underwent elective SRIH had co-morbidities that did not affect their routine life or limit quality of life.

In contrast, the patients who underwent emergency SRIH had severe comorbidities that affected daily life, leading to increased perioperative morbidity and mortality rates.

Previous studies have suggested reduction of incarcerated hernia in elderly patients; however, long-term follow-up studies later described reduction as temporary treatment option due to high incidence of re-incarceration. ${ }^{[18]}$ Therefore, post-reduction repair in shortest possible time under elective conditions should be recommended as permanent solution. In this group of patients, emergency SRIH is reported to be associated with high risk of morbidity and mortality due to need for laparotomy and small bowel resection. ${ }^{[19-21]}$ In patients who present with history of incarceration for more than 6 hours, resection is usually performed, which increases risk of mortality by 20 times. ${ }^{[21,22]}$ Kulah et al. ${ }^{[23]}$ demonstrated that risk of strangulation and small bowel resection is signifi- 
cantly increased in patients with more than 48 hours between onset of symptoms and presentation. Intestinal complications are 4 times likely to occur in femoral hernia compared with inguinal hernia. ${ }^{[21]}$ In our study, which included only elderly patients with high ASA score, incidence of small bowel resection was higher in patients who had emergency SRIH (21\%) compared with those who underwent elective repair. Incidence of laparotomy was $5.5 \%$ in Group ER. Factors affecting morbidity were small bowel resection, low albumin level, and associated wound infection. Low albumin level is known to be responsible for longer ICU/hospital stay. ${ }^{[2]}$ In our study, ICU/hospital stay and ESRD were found to be predictors of morbidity, and ASA score of IV or higher, ESRD, incision type, and anesthesia type were determined to be independent predictors of mortality. Postoperative complications were significantly associated with longer ICU/hospital stay. We could not determine value of low albumin, since albumin level is not part of routine biochemical work-up at our hospital in emergency setting.

Primatesta et al. ${ }^{[16]}$ reported emergency SRIH rate of only $9 \%$ in their analysis of over 30000 SRIH cases in which $91 \%$ of the patients were male and there was mean age of 58 years. Mortality was significantly associated with emergency SRIH. Similar study by Martínez-Serrano et al. ${ }^{[2]}$ that included patients over age of 70 years who underwent emergency abdominal hernia repair documented mortality rate of $4.5 \%$. Mortality rate in our patient group was II\%. Higher rate than reported previously may be associated with higher ASA scores and greater age. Mean age of all patients in our study who died was 82 years, and 9 of the 10 patients had ASA score of IV while remaining patient had ASA score of V. Expected mortality in patients with ASA score of IV ranges between $7.8 \%$ and $23 \%$, and that of patients with ASA score of $\mathrm{V}$ is between $9.4 \%$ and $51 \%$. Although II\% mortality appears high in comparison with previous reports, it is far below expected mortality considering high ASA scores of our patients. Some studies have determined that small bowel resection was not predictive factor for mortality, but those patients did have higher rate of wound infections and longer hospital stay. [22,25] In present study, ASA score of IV, underlying co-morbid condition, specifically ESRD, and postoperative complications were among factors that predicted mortality.

In conclusion, emergency SRIH is associated with high risk of mortality and morbidity in elderly patients with higher ASA classification. Small bowel resection may be required and length of hospital stay may be prolonged. As supported by findings from our study, we suggest elective SRIH be performed in geriatric patients with high ASA score after appropriate preoperative anesthesia assessment and surgical risk evaluation.

\section{Acknowledgement}

There is no acknowledgement to declare.
Conflict of interest: None declared.

\section{REFERENCES}

1. www.tuik.gov.tr/PreIstatistikTablo.do?istab_id=945 (31.12.2015)

2. Kulaçoğlu H, Polat A, Moran M, Gök R, Coşkun F. Electıve ınguınal hernia reparr in the elderly. Turk Geriatri Derg 2000;3:64-8.

3. Miserez M, Peeters E, Aufenacker T, Bouillot JL, Campanelli G, Conze J, et al. Update with level 1 studies of the European Hernia Society guidelines on the treatment of inguinal hernia in adult patients. Hernia 2014;18:151-63. Crossret

4. Malik AM, Khan A, Talpur KA, Laghari AA. Factors influencing morbidity and mortality in elderly population undergoing inguinal hernia surgery. J Pak Med Assoc 2010;60:45-7.

5. Mansouri M, Ekjam S, Hudairi A, Sannussi OI, Fakheri A. Emergency abdominal surgery in Libyan elderly patients. Sci Med J 2005;17:57-65.

6. Turrentine FE, Wang H, Simpson VB, Jones RS. Surgical risk factors, morbidity, and mortality in elderly patients. J Am Coll Surg 2006;203:865-77. Crossre]

7. Zenilman ME. Surgery in the elderly. Curr Probl Surg 1998;35:99-179.

8. Demir U, Mihmanli M, Coskun H, Dilege E, Kalyoncu A, Altinli E, et al. Comparison of prosthetic materials in incisional hernia repair. Surg Today 2005;35:223-7. Crossre

9. Pavlidis TE, Symeonidis NG, Rafailidis SF, Psarras K, Ballas KD, Baltatzis ME, et al. Tension-free by mesh-plug technique for inguinal hernia repair in elderly patients. Scand J Surg 2010;99:137-41. Crossret

10. INCA Trialists Collaboration. Operation compared with watchful waiting in elderly male inguinal hernia patients: a review and data analysis. J Am Coll Surg 2011;212:251-9. Crossre

11. Amato B, Compagna R, Fappiano F, Rossi R, Bianco T, Danzi M, et al. Day-surgery inguinal hernia repair in the elderly: single centre experience. BMC Surgery 2013;13:28. Crossre.

12. Dunne JR, Malone DL, Tracy JK, Napolitano LM. Abdominal wall hernias: risk factors for infection and resource utilization. J Surg Res 2003;111:78-84. Crossre

13. Williams JS, Hale HW. The advisability of inguinal herniorrhaphy in the elderly. Surg Gynecol Obstet 1966;122:100-4.

14. Abete P, Cherubini A, Di Bari M, Vigorito C, Viviani G, Marchionni $\mathrm{N}$, et al. Does comprehensive geriatric assessment improve the estimate of surgical risk in elderly patients? An Italian multicenter observational study. Am J Surg 2016;211:76-83.

15. Gunnarsson U, Degerman M, Davidsson A, Heuman R. Is elective hernia repair worthwhile in old patients? Eur J Surg 1999;165:326-32. Crossref

16. Primatesta $\mathrm{P}$, Goldacre MJ. Inguinal hernia repair: incidence of elective and emergency surgery, readmission and mortality. Int J Epidemiol 1996;25:835-9. Crossret

17. Rutkow IM, Robbins AW. Classification systems and groin hernias. Surg Clin North Am 1998;78:1117-27. Crossre

18. Nehme AE. Groin hernias in elderly patients. Management and prognosis. Am J Surg 1983;146:257-60. Crossre-

19. Kekeç Y, Alparslan A, Demirtaş S, Ezici H, Altınay R. The Effects of Strangulation on Morbidity and Mortality in Irreductible Hernias. Ulus Cerrahi Derg 1993;9:128-31.

20. Rai S, Chandra SS, Smile SR. A study of the risk of strangulation and obstruction in groin hernias. Aust N Z J Surg 1998;68:650-4. Crossree

21. Nilsson H, Stylianidis G, Haapamäki M, Nilsson E, Nordin P. Mortality after groin hernia surgery. Ann Surg 2007;245:656-60. Crossrel

22. Kurt N, Oncel M, Ozkan Z, Bingul S. Risk and outcome of bowel re- 
section in patients with incarcerated groin hernias: retrospective study. World J Surg 2003;27:741-3. Crossree

23. Kulah B, Duzgun AP, Moran M, Kulacoglu IH, Ozmen MM, Coskun F. Emergency hernia repairs in elderly patients. Am J Surg 2001;182:4559. Crossre

24. Martínez-Serrano MA, Pereira JA, Sancho JJ, López-Cano M, Bom- buy E, Hidalgo J. Risk of death after emergency repair of abdominal wall hernias. Still waiting for improvement. Langenbecks Arch Surg 2010;395:551-6. Crossret

25. Alvarez JA, Baldonedo RF, Bear IG, Solís JA, Alvarez P, Jorge JI. Incarcerated groin hernias in adults: presentation and outcome. Hernia $2004 ; 8: 121-6$. Crossre.

\section{ORIJIINAL ÇALIŞMA - ÖZET}

\section{Yüksek riskli geriatrik hastalarda inguinal hernilere yaklaşım: Elektif mi, acil mi olmalıdır? \\ Dr. Rıza Gürhan Işıl, ${ }^{1}$ Dr. Pınar Yazıcı, ${ }^{1}$ Dr. Uygar Demir, ${ }^{1}$ Dr. Cemal Kaya, ${ }^{1}$ Dr. Özgür Bostancı, ${ }^{1}$ Dr. Ufuk Oğuz İdiz,, ${ }^{1}$ Dr. Canan Tülay Işıl, ${ }^{2}$ Dr. Mahmut Kaan Demircioğlu, ${ }^{1}$ Dr. Mehmet Mihmanlı,}

${ }^{1}$ Şişli Hamidiye Etfal Eğitim ve Araştırma Hastanesi, Genel Cerrahi Kliniği, İstanbul

${ }^{2}$ Şişli Hamidiye Etfal Eğitim ve Araştırma Hastanesi, Anestezi ve Reanimasyon Kliniği, İstanbul

AMAÇ: Ilerleyen yaşla birlikte inguinal herni insidansı artmaktadır. Bu hasta grubunda komorbiditelerin de artması inguinal herniye yaklaşımda cerrahiyi arka plana atmakta ve acil girişim oranlarını artırmaktadır. Bu çalışmada, inguinal herni nedeniyle ameliyat edilen yüksek riskli geriatrik hastalarda elektif ve acil yaklaşım sonuçlarını karşılaştırmalı olarak incelemeyi amaçladık.

GEREÇ VE YÖNTEM: Ocak 2010 ve Aralık 2014 tarihleri arasında kliniğimizde inguinal bölge fıtıkları nedeni ile ameliyat edilen geriatrik ( $\geq 65$ yaş) hastalar arasından yüksek riskli (ASA III ve üzeri) 384 hastanın dosyası geriye dönük olarak incelendi. Bu hastalar elektif $(n=3$ I2) ve acil $(n=72)$ operasyon olarak iki grupta incelendi. Tüm hastaların demografik özellikleri, ASA skoru, operasyon prosedürleri (insizyon şekli, ek prosedürler, anestezi tipi), yoğun bakım ve hastanede kalıs süreleri, morbidite ve mortalite parametreleri kaydedildi.

BULGULAR: Demografik özellikler Grup 2'de anlamlı yüksek ASA IV oranı hariç benzerdi. Bağırsak rezeksiyonu riski \% I ve karşı \%2। olarak Grup 2'de anlamlı yüksek izlendi. Hastanede (I.3 güne 7.9 gün, sırasıyla, $\mathrm{p}<0.0$ I) ve yoğun bakımda kalış süreleri de Grup 2'de anlamlı uzun bulundu. Ameliyat sonrası morbidite (\% I'e karşı \%24, $\mathrm{p}<0.0$ I) ve mortalite (\%0.3'e karşı \% I I, p<0.0I) Grup 2'de anlamlı yüksek saptandı. Ameliyat sonrası komplikasyon üzerine etki gösteren bağımsız parametreler arasında böbrek yetersizliği, yoğun bakım ve hastanede kalış süreleri bulunurken; mortalite üzerine etkiyen bağımsız faktörler arasında ASA skoru, böbrek yetersizliği, insizyon şekli (laparotomi) ve anestezi türü (genel anestezi) saptandı. TARTIŞMA: Elektif inguinal herni ile karşılaştırıldığında, ASA skoru yüksek yaşlı hastalarda acil olarak uygulanan inguinal herni operasyonları daha yüksek morbidite ve mortalite ile seyretmektedir. Daha sık bağırsak rezeksiyon ihtiyacı ve anlamlı uzun hastanede kalış sürelerini de dikkate alarak inguinal herni tanısı alan yüksek riskli yaşlı hastalarda da elektif operasyon uygulanmasını öneriyoruz.

Anahtar sözcükler: Acil operasyon; geriatrik; inkarserasyon; inguinal herni; yüksek riskli. 